\title{
Cost Effectiveness of Replacing Sand with Crushed Granite Fine (CGF) In the Mixed Design of Concrete
}

\author{
Engr. Muritala Ashola ADIGUN, B.Eng; M.Sc \\ Civil Engineering Department, Lagos State Polytechnic, Ikorodu, Lagos State, Nigeria.
}

\begin{abstract}
The economic gain of replacing sand with Crushed Granite Fines in the production of concrete was investigated. Compressive strength and slump tests were performed on fresh and hardened concrete using two nominal mixes of 1:1:2 and 1:11/2:3 with the sand component being partially replaced with Crushed Granite Fines. Compressive strength values above $30 \mathrm{~N} / \mathrm{mm}^{2}$ and $35 \mathrm{~N} / \mathrm{mm}^{2}$ were obtained for nominal mixes of 1:1:2 and 1:11/2: 3 respectively when sand was partially replaced with $25-37.5 \%$ Crushed Granite Fines.

Based on the economic analysis of the test results, replacement of sand with $25-37.5 \%$ Crushed Granite Fines is recommended for use in concrete production.
\end{abstract}

Keywords: Compressive Strength, Concrete, Cost, Crushed Granite Fine, Sand.

\section{Introduction}

Concrete is composed mainly of three materials, namely, cement, water and aggregate. An additional material, known as admixture, is only added at times to modify some of its properties. While cement remains the only chemically active constituent when mix with water, the aggregates seemingly play no part in the chemical reactions. However the aggregate's usefulness arise because it is an economic filler with good resistance to volume changes which occur within the concrete after mixing, as well as improving the durability of the concrete.

Aggregate is much cheaper than cement and maximum economy can be obtained by using as much aggregate as possible in the concrete while still retaining the required strength. It has also been noted by [1] that the commonly held view that aggregate is completely inert filler is not true. Its physical characteristics and in some cases its chemical composition affects to a varying degree the properties of concrete in both fresh and hardened states.

Concrete mix design can be define as the process of selecting and determining the relative amounts of suitable constituents of concrete to produce concrete of required strength, workability and durability at minimum cost.

The required performance of concrete in both plastic and the hardened states is a factor in proportioning of concrete constituents. A plastic concrete that is not workable cannot be properly placed and compacted. The property of workability, therefore, becomes of vital factor. Also, the compressive strength of hardened concrete which is an index of its other properties, depends upon many factors such as quality and quantity of cement, water, aggregates, batching, mixing, placing, compaction and curing.

Attempts have been made by researchers in identifying some materials such as laterite, slag, fly ash, limestone powder and silicon powder as alternatives to sand in concrete. [2,3 \& 4]. In Lagos, as well as other parts in the South-West Nigeria, major sources of sand used as fine for concrete are the river beds especially, the Ogun River. The high demand for this sand arising from the ever-growing infrastructural development is always resulting in high price of the sand. Conversely, Crushed Granite Fines which is a by-product of quarry activities is readily available at the various quarry sites scattered all over South-West Nigeria. This by-product material which ordinarily causes environmental load and disposal problem at the quarry can be turned into valuable resources when used as fine aggregate in concrete production.

The overall cost of concrete is made up of the cost of materials, plant and labour. The variations in the cost of materials arise from the fact that the cement is several times costly than the aggregate, hence, the aim is to produce mix using the least quantity of cement required in producing desired strength. Technically, lower cement content results in lower heat of hydration and hence reduces shrinkage cracks while rich mixes may result in high shrinkage and cracking in the structural concrete.

Concrete is used in all fields of civil engineering. A reduction in the cost of concrete automatically translates into reduction in cost of civil engineering projects without compromising quality. The continual and increasing needs for infrastructural development in developing countries like ours is putting pressure on the supply of natural sand. This has been noted to be responsible for increase in price of sand and eventual cost of concrete. [5]. 
In this study, an investigation was carried out into the possibility and effectiveness of reducing cost of producing concrete by replacing sand with Crushed Granite Fine, i.e, stone-dust ( a by-product of rock-crushing at quarry).

This study involves experimental investigation into some properties of concrete using Crushed Granite Fine as part of the fine aggregate. The mix proportions were varied and attempt made at comparing the compressive strengths with the standard strength. The characteristic compressive strength at 7, 1421 and 28 days were found for each design mix.

\section{Materials And Methods}

\subsection{Materials}

The Granite and Crushed Granite Fine used were obtained from RCC Quarry at Ibadan. The sand was obtained locally in Lagos. The aggregates samples were graded by carrying out the grain size distribution tests on them. In all the mixes made, Larfage brand of Ordinary Portland Cement was used for the production of the concrete cubes. TABLE 1 and TABLE 2 show the results of the grading tests while TABLE 3 shows some physical and mechanical properties of the aggregates.

TABLE 1 :- Sieve Analysis of Coarse Aggregate (Granite)

\begin{tabular}{|l|c|c|}
\hline $\begin{array}{c}\text { SIEVE SIZE } \\
(\mathrm{mm})\end{array}$ & $\begin{array}{c}\text { PERCENTAGE } \\
\text { PASSING }\end{array}$ & BS 882 REQUIREMENTS [6] \\
\hline 19 & 100 & $85-100$ \\
\hline 9.52 & 16 & $0-25$ \\
\hline 4.76 & 0 & $0-5$ \\
\hline
\end{tabular}

TABLE 2 :- Sieve Analysis of Fine Aggregate (Sand And Crushed Granite Fine)

\begin{tabular}{|c|c|c|c|}
\hline \multirow{2}{*}{ SIEVE SIZE (mm) } & \multicolumn{2}{|c|}{ PERCENTAGE PASSING } & \multirow{2}{*}{ BS 882 REQUIREMENTS [6] } \\
\cline { 2 - 4 } & Sand & $\begin{array}{c}\text { Crushed Granite } \\
\text { Fine }\end{array}$ & $89-100$ \\
\hline $4.75 \mathrm{~mm}$ & 100 & 100 & $60-100$ \\
\hline $2.36 \mathrm{~mm}$ & 81 & 64 & $30-100$ \\
\hline $1.18 \mathrm{~mm}$ & 49 & 38 & $15-100$ \\
\hline $600 \mu$ & 30 & 21 & $5-70$ \\
\hline $300 \mu$ & 9 & 6 & \\
\hline $150 \mu$ & 5 & 2 & \\
\hline Fineness Modulus & 3.26 & 3.69 & \\
\hline
\end{tabular}

TABLE 3:- Some Physical Properties of Constituent Materials

\begin{tabular}{|l|l|l|}
\hline MATERIAL & SPECIFIC GRAVITY & SHAPE \\
\hline Cement & 3.15 & - \\
\hline Granite (Coarse Aggregate) & 2.72 & Crushed Irregular \\
\hline Sand (Fine Aggregate) & 2.67 & Irregular \\
\hline Crushed Granite Fine (Fine Aggregate) & 2.71 & Crushed Irregular \\
\hline
\end{tabular}

\subsection{Methods}

Two nominal mixes of 1:1:2 and 1:1 1/2:3 were used for concrete grades 25 and 30 respectively. A water/cement ratio of 0.42 and 0.45 were used for the two mixes respectively.

The batching was done by volume with the mix produced with only sand as fine aggregate serving as the control mix. The replacement of Crushed Granite Fine in the fine aggregate constituent was varied from $0-$ $100 \%$ in the two trial mixes. Detail of the mix proportions are as indicated in Table 4 . The batched materials were mixed with water in accordance with [7]. The fresh concrete was sampled and tested for slump in accordance with [8].

The concrete cubes specimens were casted in two layers, each layer being vibrated for about 1 minute. The specimens' surface were troweled flat and covered with polythene sheets until remolding after 24 hours. After remolding, they were carefully placed inside a curing tank for curing in water at $26 \pm 2{ }^{\circ} \mathrm{C}$ until test.

The compressive strength of the hardened concrete cubes were tested for at 7, 14, 21 and 28 days hydration. On the average, at least twenty-seven specimens were tested for each trial mix at each of the 7, 14, 21 and 28 days hydration periods.

\section{Test Results And Discussion}

Some physical and mechanical properties of the Granite, Crushed Granite Fine and Sand used are as given in TABLE 3. The Granite, Crushed Granite Fines and Sand have apparent specific gravity of 2.72, 2.71 and 2.67 respectively. All the aggregates specific gravity values lie within the range requires for normal weight 
aggregates (i.e 2.5 to 3.0). The particle size distribution test shows that the maximum size of the coarse aggregate is $20 \mathrm{~mm}$. The concrete bulk densities of all the mixes produced range between $2300 \mathrm{~kg} / \mathrm{m}^{3}$ and 2520 $\mathrm{kg} / \mathrm{m}^{3}$ at 28 days hydration indicating that despite the introduction of Crushed Granite Fines, concrete with densities within the density range of normal weight concrete can still be achieved.

The slumps values range from 45 to $51 \mathrm{~mm}$ with the water-cement ratio values ranging between 0.42 and 0.50 . The results also show that water-cement ratio and slump values increase with increase in the quantity of Crushed Granite Fines used as sand replacement. This effect can be attributed to higher amount of water required for lubrication of Crushed Granite Fines.

The results of the development of compressive strength with Crushed Granite Fines contents for 1:1:2 and 1:1 1/2:3 mixes concrete are presented in TABLE 4. The variation of Compressive Strength with different Crushed Granite Fines contents are as plotted in Fig. 1 and Fig. 2 for 1:1:2 and 1:11/2:3 mixes respectively.

The results indicated that in every case, the compressive strength continue to increase with age. The mix where sand is completely replaced by Crushed Granite Fines gave the least strength in both cases. The mix with highest strength is obtained when the amount of Crushed Granite Fine used in replacing sand is between 25 and $37.5 \%$. Also at 50\% sand replacement by Crushed Granite Fine, the compressive strength achieved is higher in value than the standard value for the nominal mix in question, It is interesting to note that a value of 30.26 $\mathrm{N} / \mathrm{mm}^{2}$ is achieved with $1: 1 \frac{1}{2}: 3$ mix which ordinarily would have been $25 \mathrm{~N} / \mathrm{mm}^{2}$ when only sand is used as fine aggregate. Similarly, a value of $35.23 \mathrm{~N} / \mathrm{mm}^{2}$ is achieved with $1: 1: 2$ mix which ordinarily would have been $30 \mathrm{~N} / \mathrm{mm}^{2}$ when only sand is used as fine aggregate.

The increase in compressive strength values as a result of partial replacement of sand with crushed granite fines can be attributed to frictional resistance's component's contribution to compressive strength arising from the rough and irregular nature of Crushed Granite Fines particles that fills the voids between the granite and sand particles while cement acts as binder for the components.

TABLE 4: Compressive Strength of Concrete for Trial Mixes

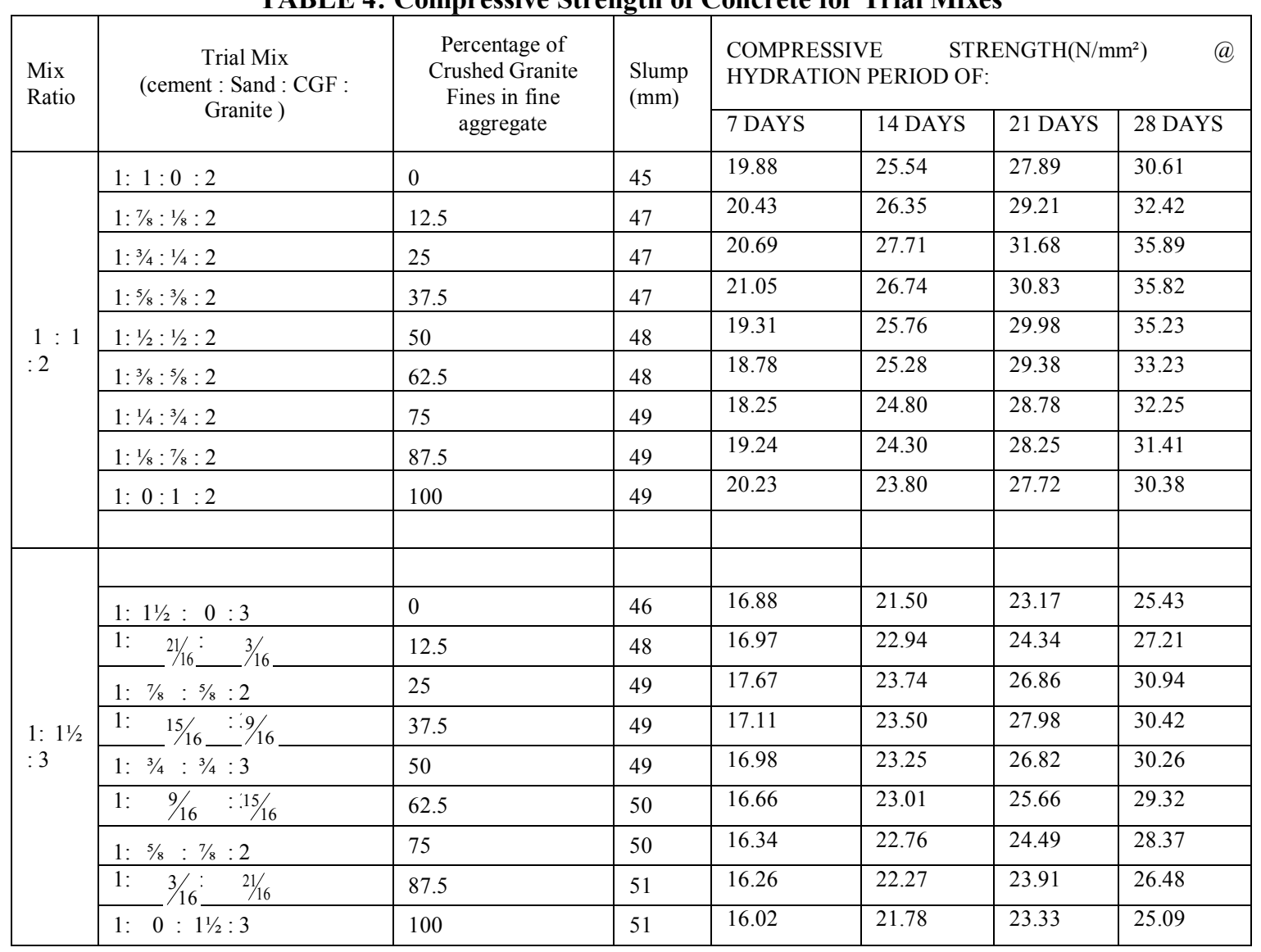




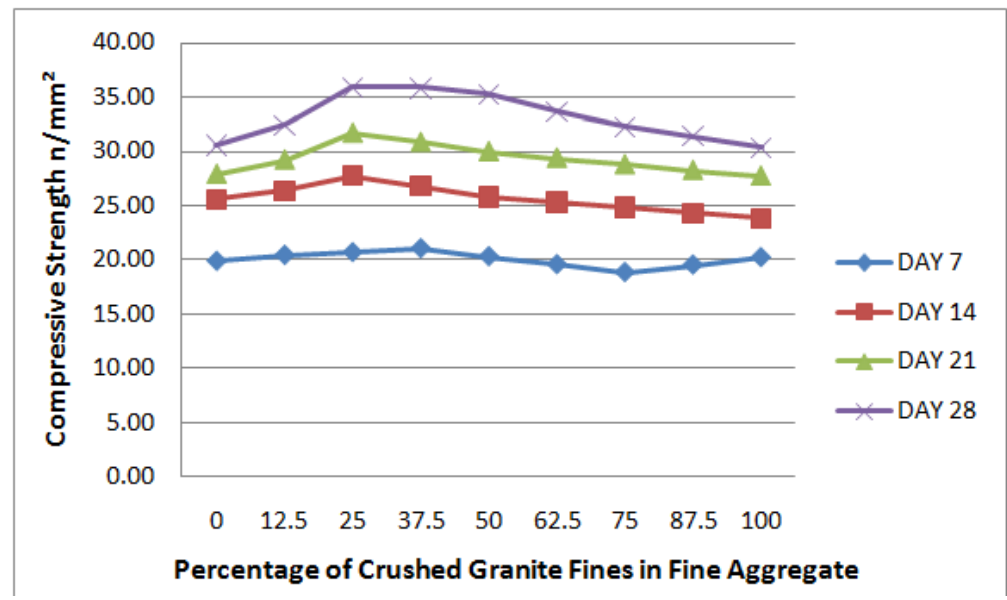

Fig. 1 - Compressive Strength Development at Different Percentage of Crushed Granite Fines for 1:1:2 Nominal Mix

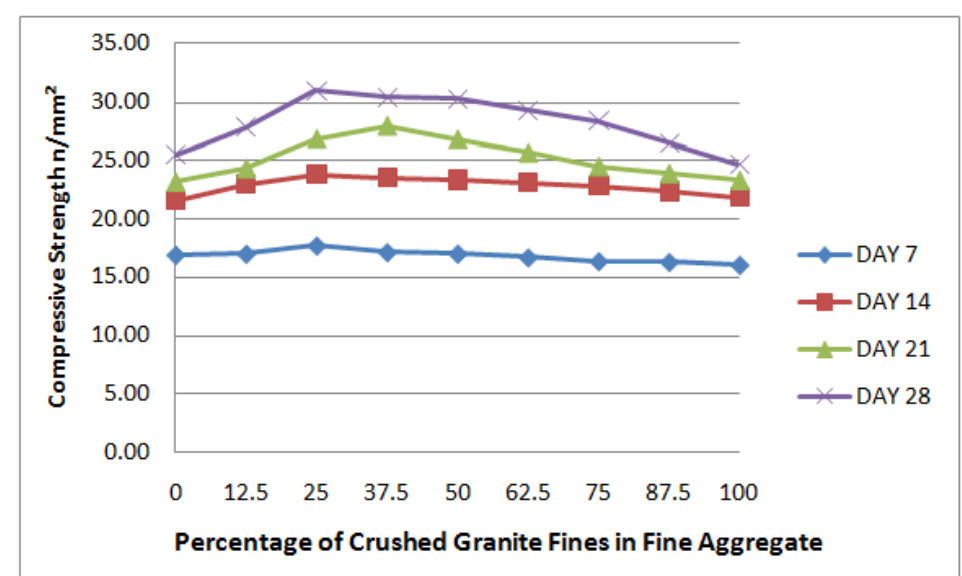

Fig. 2 - Compressive Strength Development at Different Percentage of Crushed Granite Fines for 1: 11/2:3 nominal Mix

\section{Economic Analysis Of Replacement}

From the test results, it is observed that a mix design of 1:1 $1 / 2: 3$ can by this replacement arrangement yield a compressive strength of $30 \mathrm{~N} / \mathrm{mm}^{2}$ against 1:1:2 mix required to yield this strength when only sand is used as fine aggregate. Thus, a higher strength value at lower mix ratio can be achieved by this arrangement.

The approximate quantities of concrete constituents required to produce normal concrete mixes of 1:1:2 and 1:1 1/2:3 are as shown in TABLE 5 below.

TABLE 5: Quantities per unit volume of concrete constituents

\begin{tabular}{|l|l|l|}
\hline \multirow{2}{*}{ CONCRETE } & APPROXIMATE QUANTITIES PER UNIT VOLUME OF MIXED \\
& CONCRETE & $1: 1 \frac{1}{2}: 3$ \\
\cline { 2 - 3 } & $1: 1: 2$ & $360 \mathrm{~kg}(7.2 \mathrm{bags})$ \\
\hline Cement & $485 \mathrm{~kg}(9.7 \mathrm{bags})$ & $0.38 \mathrm{~m} 3$ \\
Fine Aggregate & $0.34 \mathrm{~m} 3$ & $0.76 \mathrm{~m} 3$ \\
Coarse Aggregate & $0.69 \mathrm{~m} 3$ & \\
\hline
\end{tabular}

The cost of materials needed to produced one cubic meter of concrete at different replacement percentage for the two nominal mixes are presented in TABLE 6a and TABLE 6b. TABLE 7 shows cost comparison between using only sand and when sand is replaced with Crushed Granite Fines at $25 \%$ and $37.5 \%$ for concrete grade 30 and 35 . 
Table 6a: Cost of Replacing Sand with different percentages of Crushed Granite Fines in 1 cubic meter of Concrete at 1:1:2 Mix Ratio

\begin{tabular}{|c|c|c|c|c|c|r|r|r|r|}
\hline $\begin{array}{c}\text { Percentage } \\
\text { of Crushed } \\
\text { Granite } \\
\text { Fines }\end{array}$ & $\begin{array}{c}\text { Cement } \\
(\mathrm{kg})\end{array}$ & $\begin{array}{c}\text { Sand } \\
\left(\mathrm{m}^{3}\right)\end{array}$ & $\begin{array}{c}\text { Crushed } \\
\text { Granite } \\
\text { Fine } \\
\left(\mathrm{m}^{3}\right)\end{array}$ & $\begin{array}{c}\text { Granite } \\
\left(\mathrm{m}^{3}\right)\end{array}$ & $\begin{array}{c}\text { Cement } \\
(\mathrm{kg})\end{array}$ & $\begin{array}{c}\text { Sand } \\
\left(\mathrm{m}^{3}\right)\end{array}$ & $\begin{array}{c}\text { Crushed } \\
\text { Granite } \\
\text { Fine } \\
\left(\mathrm{m}^{3}\right)\end{array}$ & $\begin{array}{c}\text { Cost of Materials in Naira } \\
\text { Granite } \\
\left(\mathrm{m}^{3}\right)\end{array}$ & $\begin{array}{c}\text { TOTAL COST } \\
\text { N } \\
\text { K }\end{array}$ \\
\hline 0 & 485 & 0.3400 & 0.0000 & 0.69 & $17,460.00$ & $1,224.00$ & 0.00 & $4,657.50$ & $23,341.50$ \\
\hline 12.5 & 485 & 0.2975 & 0.0425 & 0.69 & $17,460.00$ & $1,071.00$ & 165.75 & $4,657.50$ & $23,354.25$ \\
\hline 25 & 485 & 0.2550 & 0.0850 & 0.69 & $17,460.00$ & 918.00 & 331.50 & $4,657.50$ & $23,367.00$ \\
\hline 37.5 & 485 & 0.2125 & 0.1275 & 0.69 & $17,460.00$ & 765.00 & 497.25 & $4,657.50$ & $23,379.75$ \\
\hline 50 & 485 & 0.1700 & 0.1700 & 0.69 & $17,460.00$ & 612.00 & 663.00 & $4,657.50$ & $23,392.50$ \\
\hline 62.5 & 485 & 0.1275 & 0.2125 & 0.69 & $17,460.00$ & 459.00 & 828.75 & $4,657.50$ & $23,405.25$ \\
\hline 75.5 & 485 & 0.0850 & 0.2550 & 0.69 & $17,460.00$ & 306.00 & 994.50 & $4,657.50$ & $23,418.00$ \\
\hline 87.5 & 485 & 0.0425 & 0.2975 & 0.69 & $17,460.00$ & 153.00 & $1,160.25$ & $4,657.50$ & $23,430.75$ \\
\hline 100 & 485 & 0.0000 & 0.3400 & 0.69 & $17,460.00$ & 0.00 & $1,326.00$ & $4,657.50$ & $23,443.50$ \\
\hline
\end{tabular}

Table 6b: Cost of Replacing Sand with different percentages of Crushed Granite Fines in 1 cubic meter of Concrete at 1:11/2:3 Mix Ratio

\begin{tabular}{|c|c|c|c|c|c|r|r|r|r|}
\hline $\begin{array}{c}\text { Percentage } \\
\text { of Crushed } \\
\begin{array}{c}\text { Granite } \\
\text { Fines }\end{array}\end{array}$ & $\begin{array}{c}\text { Cement } \\
(\mathrm{kg})\end{array}$ & $\begin{array}{c}\text { Sand } \\
\left(\mathrm{m}^{3}\right)\end{array}$ & $\begin{array}{c}\text { Crushed } \\
\text { Granite } \\
\text { Fine } \\
\left(\mathrm{m}^{3}\right)\end{array}$ & $\begin{array}{c}\text { Granite } \\
\left(\mathrm{m}^{3}\right)\end{array}$ & $\begin{array}{c}\text { Cement } \\
(\mathrm{kg})\end{array}$ & $\begin{array}{c}\text { Sand } \\
\left(\mathrm{m}^{3}\right)\end{array}$ & $\begin{array}{c}\text { Crushed } \\
\text { Granite } \\
\text { Fine } \\
\left(\mathrm{m}^{3}\right)\end{array}$ & $\begin{array}{c}\text { Cost of Materials in Naira } \\
\text { Granite } \\
\left(\mathrm{m}^{3}\right)\end{array}$ & $\begin{array}{c}\text { TOTAL COST } \\
\text { N } \\
\text { K }\end{array}$ \\
\hline 0 & 360 & 0.3600 & 0.0000 & 0.72 & $12,960.00$ & $1,296.00$ & 0.00 & $4,860.00$ & $19,116.00$ \\
\hline 12.5 & 360 & 0.3150 & 0.0450 & 0.72 & $12,960.00$ & $1,134.00$ & 175.50 & $4,860.00$ & $19,129.50$ \\
\hline 25 & 360 & 0.2700 & 0.0900 & 0.72 & $12,960.00$ & 972.00 & 351.00 & $4,860.00$ & $19,143.00$ \\
\hline 37.5 & 360 & 0.2250 & 0.1350 & 0.72 & $12,960.00$ & 810.00 & 526.50 & $4,860.00$ & $19,156.50$ \\
\hline 50 & 360 & 0.1800 & 0.1800 & 0.72 & $12,960.00$ & 648.00 & 702.00 & $4,860.00$ & $19,170.00$ \\
\hline 62.5 & 360 & 0.1350 & 0.2250 & 0.72 & $12,960.00$ & 486.00 & 877.50 & $4,860.00$ & $19,183.50$ \\
\hline 75.5 & 360 & 0.0900 & 0.2700 & 0.72 & $12,960.00$ & 324.00 & $1,053.00$ & $4,860.00$ & $19,197.00$ \\
\hline 87.5 & 360 & 0.0450 & 0.3150 & 0.72 & $12,960.00$ & 162.00 & $1,228.50$ & $4,860.00$ & $19,210.50$ \\
\hline 100 & 360 & 0.0000 & 0.3600 & 0.72 & $12,960.00$ & 0.00 & $1,404.00$ & $4,860.00$ & $19,224.00$ \\
\hline
\end{tabular}

TABLE 7. Cost Comparison for Concrete Grades 30 and 35

\begin{tabular}{|c|c|c|c|c|}
\hline \multirow{2}{*}{$\begin{array}{c}\text { Grade of } \\
\text { Concrete }\end{array}$} & $\begin{array}{c}\text { Fine Aggregate Material } \\
\text { Combination }\end{array}$ & $\begin{array}{c}\text { Cost of Concrete } \\
\text { Materials using } \\
\text { only Sand }\end{array}$ & $\begin{array}{c}\text { Cost of Concrete } \\
\text { Materials using } \\
\text { Crushed Granite Fine } \\
\text { and Sand }\end{array}$ & $\begin{array}{c}\text { Difference in } \\
\text { Cost }\end{array}$ \\
\hline \multirow{2}{*}{30} & $75 \%$ Sand, 25\% CGF & $21,001.50$ & $19,486.50$ & $1,515.00$ \\
\cline { 2 - 5 } & $62,5 \%$ Sand, 37.5\% CGF & $21,001.50$ & $19,500.75$ & $1,500.75$ \\
\hline \multirow{2}{*}{35} & $75 \%$ Sand, 25\% CGF & $26,401.50$ & $23,367.00$ & 3034.50 \\
\cline { 2 - 5 } & $62,5 \%$ Sand, 37.5\% CGF & $26,401.50$ & $23,379.75$ & $3,021.75$ \\
\hline
\end{tabular}

\section{Conclusion}

The test results and the cost analysis reported in this paper showed that there are good prospects of obtaining a good concrete strength at relatively cheaper cost even while replacing part of the sand with Crushed Granite Fine. Compressive Strength of $30 \mathrm{~N} / \mathrm{mm}^{2}$ and $35 \mathrm{~N} / \mathrm{mm}^{2}$ can be obtained using a nominal mix ratio hitherto required for Compressive Strength of $25 \mathrm{~N} / \mathrm{mm}^{2}$ and $30 \mathrm{~N} / \mathrm{mm}^{2}$ respectively. Higher water-cement ratio is required when Crushed Granite Fine is used in replacing sand during concrete production.

Based on this finding, it is recommended that partial replacement of sand with $25-37.5 \%$ Crushed Granite Fines be used in concrete production where higher grade than the mix ratio is desired. Also, where there are abundant supplies of Crushed Granite Fines, replacement upto $100 \%$ may be used when the strength desired is not at variance with normal mix ratio. 


\section{References}

[1]. N. Jackson, Civil Engineering Materials (Macmillian Publishers Ltd, ${ }^{\text {rd }}$ Edition, 1984).

[2]. H.S. Uchikawa and H. Hanehara Hirao, Influence of microstructure on the physical properties of concrete prepared by substituting mineral powder for part of fine aggregate, Cement and Concrete Research, 26(1), 1996, p. 101-111.

[3]. R. Siddique, Effect of fine aggregate replacement with class F fly ash on the Mechanical Properties of Concrete. Cement and Concrete research, 33 (4), 2003, p. 539-546.

[4]. D. Adepegba, A Comparative study of normal concrete which contained laterite instead of Sand, Building Science, 1996, pp 135.

[5]. S.N. Raman, M. Safiuddin, and M.F.M Zain, Non-Destructive Evaluation of Flowing Concretes incorporating Quarry waste, Asian Journal of Civil Engineering (Building and Housing), 8(6), 2007, p. 597-614.

[6]. British Standard Institutions, Specification for aggregate for Natural Source for Concrete, BS 882, London, 1992.

[7]. British Standard Institutions, method for Making Test Cubes from Fresh Concrete, BS 1881: part 108, London, 1983.

[8]. British Standard Institutions, Methods for Determination of Slump, BS 1881: part 102, London, 1983. 